\title{
Impact of Humic Acid on Yield and Quality of Sugar Beet (Beta vulgaris L.) Grown on Calcareous Soil
}

\author{
Ghorbanali RASSAM*, Alireza DADKHAH, Asghar KHOSHNOOD YAZDI, \\ Maryam DASHTI
}

\author{
Higher Education Complex of Shirvan, Faculty of Natural and Agricultural Sciences, Department of Plant production, Shirvan, Iran; \\ rassammf@yahoo.com ("correspondingauthor);dadkhah@um.ac.ir; khoshnood@um.ac.ir;maryam.dashti.josheghan@gmail.com
}

\begin{abstract}
A field experiment was performed to determine the effects of using humic acid with irrigation on quantitative and qualitative yield traits of sugar beet grown on calcareous soils in Esfaraen, located in the North-East of Iran. Treatments consisted of three levels of humic acid concentration (zero or control, 2.5 and $5 \mathrm{~L} \mathrm{ha}^{-1}$ ) and the number of applications (once 45 days after planting; twice, 45 and 75 days after planting; three times, respectively 45, 75 and 105 days after planting). The effect of the two experimental factors on sugar beet yield traits such as the content of sucrose, refined sugar, molasses forming substances, root yield and refined sugar yield were evaluated. The results proved the existence of a significant interaction between humic acid concentration and the number of applications on all parameters under study. The application of humic acid caused a significant increase of sucrose, refined sugar, root yield and refined sugar yield and a reduction in molasses forming substances content, compared to the control. The increased amount of sucrose and refined sugar content in all applications in concentration of $2.5 \mathrm{~L} \mathrm{ha}^{-1}$ humic acid was more than with $5 \mathrm{~L} \mathrm{ha}^{-1}$. Similarly, the content of molasses forming substances showed more reduction in $2.5 \mathrm{~L} \mathrm{ha}^{-1}$ than in $5 \mathrm{~L} \mathrm{ha}^{-1}$ treatment. However, the results revealed that the highest root yield and refined sugar yield, as the main qualitative and quantitative parameters of sugar beet yield, were achieved by three times application of $5 \mathrm{~L} \mathrm{ha}^{-1}$ that had 24 and $37 \%$ increase compared to control.
\end{abstract}

Keywords: humic acid, root yield, sucrose, sugar beet

\section{Introduction}

Availability of nutrients is highly dependent on soil properties. Calcareous soils are among the most important factors limiting the availability of nutrients and agricultural production (Leytem and Mikkelsen, 2005; Çelik et al., 2010; Tahir et al., 2011). Calcareous soils cover more than $30 \%$ of the earth's land surface and they are the main soil of most of the arid and semi-arid climates (FAO, 1973). These soils contain different amounts of calcium carbonate $\left(\mathrm{CaCO}_{3}\right)$ that affects the physical (such as soil water relations) and chemical (such as fertility, nutrient availability) soils properties related to plant growth (FAO, 1973; Leytem and Mikkelsen, 2005). The excess of calcium carbonate increases soil $\mathrm{pH}$, whereas a $\mathrm{pH}$ higher than 8 (up to 8.4) leads to reduced access to micronutrients, emissions of ammonium and reduced solubility and phosphorus uptake (Katkat et al., 2009; Çelik et al., 2010). In addition, calcareous soils in warmer regions are naturally low in organic matter due to high temperature (Leytem and Mikkelsen, 2005; Çelik et al., 2010).

Humus substances (humic and fulvic acids) constitute 65$70 \%$ of organic matter in soils and the term bumus is widely accepted as synonymous for soil organic matter (Chen and
Aviad, 1990). The major functional groups of humic acids include carboxyl, phenolic hydroxyl, alcoholic hydroxyl, ketone and quinoid (Russo and Berlyn, 1990). Humic compounds have multiple roles which can significantly improve plant growth. It has been shown that the use of humic compounds improves the properties of soil (such as aggregation, aeration, permeability, water-holding capacity), enhance the uptake of macro and microelements, increase cell permeability, has stimulating effect on respiration, photosynthesis, protein and nucleic acid synthesis, modulates the activity of $\mathrm{H}^{+}$-ATPase in plasmalema and tonoplast, increase chlorophyll content, enhance stress tolerance, increase activity of soil microbial populations and hormonal regulation of plant (Visser, 1985; Chen and Aviad, 1990; Russo and Berlyn, 1990; Muscolo et al., 1993; Nardi et al., 2002; Tan, 2003). The positive effects of humic acid on the growth and yield of some plants such as wheat (Katkat et al., 2009), corn (Eyheraguibel et al., 2008), barely (Ayuso et al., 1996) and tomato (Lulakis and Petsas, 1995) have been reported. There are studies that also looked at the effect of humic acid on the qualitative and quantitative yield of sugar beet. However, the effect of humic acid on the growth and yield of sugar beet grown in calcareous soils is less studied.

It is assumed that under calcareous soils, humic acid improves the growth and yield of sugar beet and increase the 
368

Table 1. Particle size distribution and physical-chemical properties of the soil at the experimental field site

\begin{tabular}{|cc|}
\hline Texture & Loam Clay Values \\
\hline Sand $(\%)$ & 18 \\
Clay $(\%)$ & 24 \\
Silt $(\%)$ & 58 \\
$\mathrm{pH}$ & 8.05 \\
$\mathrm{EC}\left(\mathrm{ds.m}^{-1}\right)$ & 3.56 \\
Total CaCo3 $(\%)$ & 28 \\
\hline Organic matter $(\%)$ & 1.11 \\
\hline Total N $(\%)$ & 0.053 \\
$\mathrm{P}\left(\mathrm{mg} \mathrm{kg}^{-1}\right)$ & 5.45 \\
$\mathrm{~K}\left(\mathrm{mg} \mathrm{kg}^{-1}\right)$ & 415 \\
$\mathrm{Fe}\left(\mathrm{mg} \mathrm{kg}^{-1}\right)$ & 2.15 \\
$\mathrm{Zn}\left(\mathrm{mg} \mathrm{kg}^{-1}\right)$ & 0.23 \\
$\mathrm{Cu}\left(\mathrm{mg} \mathrm{kg}^{-1}\right)$ & 0.88 \\
$\mathrm{Mn}\left(\mathrm{mg} \mathrm{kg}^{-1}\right)$ & 5.45 \\
\hline
\end{tabular}

absorption of nutrients as a result. Therefore, this study was conducted to investigate the effect of humic acid on the yield and quality of sugar beet grown in calcareous soils.

\section{Materials and Methods}

The field experiment was conducted in Esfaraen in North-Eastern Iran. The area has a dry climate (with warm and dry summers) with an average annual rainfall of $270 \mathrm{~mm}$ and the mean temperature of $15^{\circ} \mathrm{C}$. The meteorological data were collected from weather stations near the experiment field. The soil is Aridisol according to U.S. soil taxonomy. The soil in the area is characterized by large amounts of calcium carbonate (containing 28\%). The existence of this amount of calcium carbonate limits the growth of crops in the area. Other soil properties are presented in Table 1.

The experiment was organized following a factorial randomized complete-block design, with three replications. The factors were: different concentrations of humic acid $\left(0,2.5,5 \mathrm{~L} \mathrm{ha}^{-1}\right)$ and the number of applications (once at 45 days after planting; twice at 45 and 75 days after planting; three times at 45,75 and 105 days after planting respectively). Humic acid was used along with irrigation in specified concentrations and time.

The sugar beet seeds were sown by hand at the density of 120,000 plants $h^{-1}$ on 24 June 2013. Each plot consisted of 6 rows of $4 \mathrm{~m}$ at $50 \mathrm{~cm}$ spacing in between. Based on the soil test results, nitrogen, phosphorus and potassium fertilizers in the recommended amounts were added to the ground before planting. Weeds, diseases and insects were controlled continuously throughout the growing season.

Harvesting was done on 18 November 2013. A representative sample from each plot (selecting 4 rows of $3 \mathrm{~m}$, by excluding plants along the plot edges) was used to measure the qualitative and quantitative parameters.

Parameters include the content of sucrose, refined sugar, molasses forming substances ( $\mathrm{Na}, \mathrm{K}$ and amino$\mathrm{N})$, root yield and refined sugar yield.

Data were analyzed by analysis of variance using the SAS computer program (SAS Institute, 1988). Multiple comparisons of variables were made using the least significant differences (LSD) at $\mathrm{P}<0.05$.

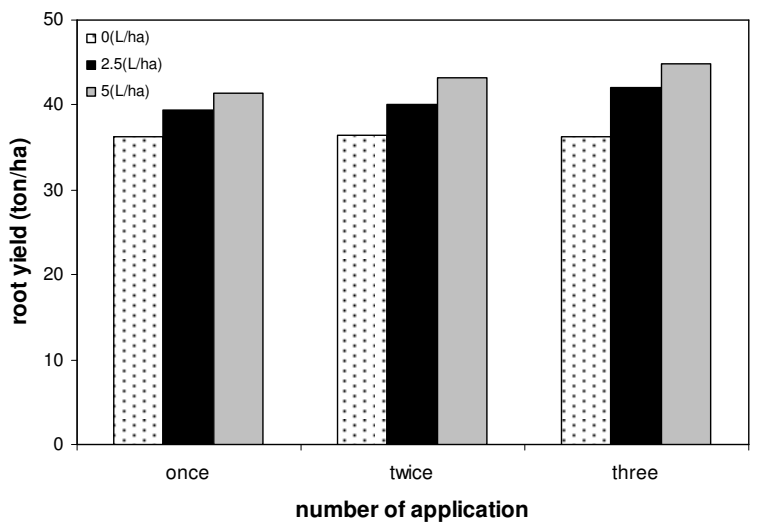

Fig. 1. Effect of humic acid concentration and the number of application(s) on root yield

\section{Results and Discussion}

The results of variance analysis showed that the effect of different concentrations, number of applications and the interaction effect of concentration and the number of applications of humic acid were statistically significant on all qualitative and quantitative parameters studied for sugar beet grown on calcareous soil (Table 2 ).

\section{Root yield}

The application of humic acid increased sugar beet root yield compared to control (Fig. 1). For any number of applications, the greatest increase in the root yield compared to control was witnessed when $5 \mathrm{~L} \mathrm{ha}^{-1}$ humic acid were used. Also, with the increasing number of applications of 5 $\mathrm{L} \mathrm{ha}^{-1}$ humic acid, the root yield increased by 14,19 and $24 \%$ compared to control in one, two and three times of use respectively. There are many reasons to justify the increase of the root yield caused by humic acid application especially in calcareous soils. Katkat et al. (2009) stated that in calcareous soils, due to the high $\mathrm{pH}$, the solubility of micronutrients is reduced and the plants grown in such soils encounter micronutrient deficiency. Other researchers have also reported plant growth simulation and nutrient uptake by adding humic acid (Chen and Schnitzer, 1978; Fagbenro and Agboda, 1993; David et al., 1994). In addition, positive effects of humic acid on the growth and production of plants are attributed to the hormone-like activity through its involvement in cell respiration, photosynthesis, protein synthesis, various enzymatic reactions and antioxidant effect (Vaughan, 1974; Muscolo et al., 1993; Zhang and Schmidt, 1999; Türkmen et al., 2004). Feckova et al. (2013) have reported that humic acid application increased the sugar beet root yield up to $20 \%$ compared to control (without application); the reason was due to the fact that the humate chelates complexes with microelements can get easier to the plant cell than the common ions. Sadeghi-Shoae et al. (2013) concluded that the sugar beet root yield was $25 \%$ higher in the plots containing humic acid than in plots without any added humic acid. The positive effects of humic acid in calcareous soils on other crops such as wheat (Katkat et al., 2009; Tahir et al., 2011) and maize (Çelik et al., 2010) have also been proven. 
Table 2. Variance analysis of the humic acid concentration and the number of application $(s)$ on yield and quality of sugar beet

\begin{tabular}{|c|c|c|c|c|c|c|c|c|}
\hline & & & F-values & & & & & \\
\hline $\begin{array}{l}\text { Refined sugar } \\
\text { yield }\end{array}$ & Root yield & Amino $N$ & $\mathrm{~K}$ & $\mathrm{Na}$ & $\begin{array}{l}\text { Refined sugar } \\
\text { content }\end{array}$ & $\begin{array}{l}\text { Sucrose } \\
\text { content }\end{array}$ & df & Var. Source \\
\hline 0.12 & 1.72 & 1.31 & 5.43 & 0.08 & 0.2 & 0.06 & 2 & Replication \\
\hline $787.14^{*}$ & $8874^{\prime \prime}$ & $20.32^{*}$ & $30.46^{\prime \prime}$ & $12.4^{*}$ & $195.74^{* \prime}$ & $207.24^{* \prime}$ & 2 & $\begin{array}{c}\text { Humic acid } \\
\text { concentration }(\mathrm{HA})\end{array}$ \\
\hline $15.08^{* \prime}$ & $674.1^{*}$ & $3.49^{*}$ & $16.37^{* *}$ & $2.99^{*}$ & $20.1^{* *}$ & $20.54^{* *}$ & 2 & $\begin{array}{c}\text { Number of application } \\
\text { (NA) }\end{array}$ \\
\hline \multirow[t]{2}{*}{$41.19^{\prime \prime}$} & $243.4^{*}$ & $11.55^{\prime \prime}$ & $13.95^{*}$ & $3.48^{*}$ & $28.77^{*}$ & $25.79^{*}$ & 4 & $\mathrm{HA} \times \mathrm{NA}$ \\
\hline & & & & & & & 16 & Error \\
\hline
\end{tabular}

significant at $\mathrm{P}<0.05$ and $\mathrm{P}<0.01$

Table 3. Effect of humic acid concentration and the number of application $(s)$ on sucrose content, refined sugar content and refined sugar yield

\begin{tabular}{|c|c|c|c|c|c|c|c|}
\hline Rel.\% & $\begin{array}{l}\text { Refined sugar yield } \\
\left(\mathrm{tha}^{-1}\right)\end{array}$ & Rel.\% & $\begin{array}{c}\text { Refined sugar content } \\
(\%)\end{array}$ & Rel.\% & Sucrose content (\%) & Concentrations $\left(\right.$ L ha $\left.^{-1}\right)$ & $\begin{array}{l}\text { Number of } \\
\text { application }\end{array}$ \\
\hline 100 & $4.63 \mathrm{~b}$ & 100 & $12.77 \mathrm{c}$ & 100 & $14.80 \mathrm{c}$ & 0 & \\
\hline 130 & $5.97 \mathrm{a}$ & 118 & $15.13 \mathrm{a}$ & 114 & $16.86 \mathrm{a}$ & 2.5 & Once \\
\hline 131 & $6.02 \mathrm{a}$ & 114 & $14.51 \mathrm{~b}$ & 110 & $16.3 b$ & 5 & \\
\hline 100 & $4.61 b$ & 100 & $12.76 \mathrm{c}$ & 100 & $14.82 \mathrm{c}$ & 0 & \\
\hline 131 & $6.03 a$ & 118 & $15.05 \mathrm{a}$ & 114 & $16.81 \mathrm{a}$ & 2.5 & Twice \\
\hline 131 & $6.08 a$ & 110 & $14.10 \mathrm{~b}$ & 108 & $15.97 \mathrm{~b}$ & 5 & \\
\hline 100 & $4.61 \mathrm{c}$ & 100 & $12.80 \mathrm{~b}$ & 100 & $14.83 \mathrm{~b}$ & 0 & \\
\hline 126 & $5.79 b$ & 110 & $14.06 \mathrm{a}$ & 107 & $15.87 \mathrm{a}$ & 2.5 & Thrice \\
\hline 138 & $6.35 \mathrm{a}$ & 110 & $14.02 \mathrm{a}$ & 107 & $15.78 \mathrm{a}$ & 5 & \\
\hline
\end{tabular}

The content of sucrose and refined sugar

Applying humic acid was accompanied by increased percentage of sucrose and refined sugar compared with the control (Table 3). Nevertheless, the trend of increasing content of sucrose and refined sugar was no associated with humic acid concentration, so that in all applications the increased concentration of humic acid from 2.5 to $5 \mathrm{~L} \mathrm{ha}^{-1}$ was associated with a reduction in refined sugar and sucrose percentage. Similarly, an increase in the frequency of application of each of the concentrations reduced the content of refined sugar and sucrose. Accordingly, the content of sucrose in once application of 2.5 and $5 \mathrm{~L} \mathrm{ha}^{-1}$ humic acid was reduced from $16.86 \%$ and $16.35 \%$ to $15.87 \%$ and $15.78 \%$ in three applications and the content of refined sugar was reduced from $15.13 \%$ and $14.51 \%$ in once application of 2.5 and $5 \mathrm{~L} \mathrm{ha}^{-1}$ to $14.06 \%$ and $14.02 \%$ in three applications. It seems that an increase in humic acid application in terms of amount and frequency is negatively related with the content of sucrose and refined sugar in the root. Lee and Bartlett (1976) and David et al. (1994) reported that too much humic acid reduced its beneficial effects. Research on tomatoes grown in saline soils showed that $1 \mathrm{~g} / \mathrm{kg}$ humic acid improved some parameters, but the increased humic acid concentration to $29 \mathrm{~g} / \mathrm{kg}$ led to the reduction of the parameters under study (Türkmen $e t$ al., 2004). Researchers have reported different levels of desirable humic acid concentration to achieve maximum qualitative and quantitative yield. For example, Tan (2003) noted the amount of 400-600 $\mathrm{mg} \mathrm{L}^{-1}$, while Chen and Avid (1990) concluded that 50-300 $\mathrm{mg} \mathrm{L}^{-1}$ represents desired quantities of humic acid.

\section{Content of molasses forming substances}

The refined sugar content is dependent on many root features: morphological- size and shape, physical- tissue elasticity, physiological- intensity of constituent roots' respiration on piles before processing, chemicalsaccharose content, and content of melassigenic substance impeding sugar extraction (Rychcik and Zawislak, 2002). The main components that make it difficult to extract sugar are: potassium, sodium and alpha-amino nitrogen in the form of amino-acids (glutamic acid and aspartic acid) and amides (glutamines, asparagines). The content of molasses forming substance in roots depends mainly on the quality of soil, mineral fertilization (mostly nitrogen and potassium) and meteorological condition during the vegetation period (Rychcik and Zawislak, 2002). High content of sodium, potassium and nitrogen prevents sucrose crystallization and reduces the white sugar extraction.

Data analysis of molasses forming substances showed that they were reduced by applying humic acid (Table 4). These results are consistent with those reported by Feckova et al. (2005). Although humic acid application reduced molasses forming substances, however, the reduction percentage was lower in $5 \mathrm{~L} \mathrm{ha}^{-1}$ application compared to $2.5 \mathrm{~L} \mathrm{ha}^{-1}$ application in any number of applications. This is supported also by the data obtained by Vaughan and McDonald (1976) who stated that humic acid application in large amounts may increase the absorption capacity of the elements such as $\mathrm{Na}^{+}$in sugar beet. Changes in molasses forming substances compared with the control indicated that potassium content has the lowest variation in different concentrations and number of applications tested.

\section{Refined sugar yield}

The refined sugar yield is the most important economic parameter in sugar beet industry. The results showed that the control with $4.61 \mathrm{t} \mathrm{ha}^{-1}$ had the lowest 
370

Table 4. Effect of humic acid concentrations and the number of application(s) on content of molasses forming substances

\begin{tabular}{|c|c|c|c|c|c|c|c|}
\hline Rel.\% & $\begin{array}{l}\text { AminoN (meq. } 100 g^{-1} \\
\text { beet) }\end{array}$ & Rel\% & $\mathrm{K}$ (meq.100g ${ }^{-1}$ beet) & Rel.\% & NA (meq. $100 \mathrm{~g}^{-1}$ beet) & Concentrations $\left(\right.$ Lha $\left.^{-1}\right)$ & Number of application \\
\hline 100 & $2.31 \mathrm{a}$ & 100 & $5.90 \mathrm{a}$ & 100 & $2.42 \mathrm{a}$ & 0 & \\
\hline 73 & $1.68 \mathrm{~b}$ & 92 & $5.43 \mathrm{~b}$ & 69 & $1.66 \mathrm{~b}$ & 2.5 & Once \\
\hline 81 & $1.86 \mathrm{~b}$ & 94 & $5.56 \mathrm{c}$ & 84 & $2.03 c$ & 5 & \\
\hline 100 & $2.33 \mathrm{a}$ & 100 & $5.88 \mathrm{a}$ & 100 & $2.40 \mathrm{a}$ & 0 & \\
\hline 75 & $1.74 \mathrm{~b}$ & 88 & $5.22 c$ & 67 & $1.62 \mathrm{~b}$ & 2.5 & Twice \\
\hline 77 & $1.79 \mathrm{~b}$ & 96 & $5.66 \mathrm{~b}$ & 96 & $2.31 \mathrm{a}$ & 5 & \\
\hline 100 & $2.29 \mathrm{a}$ & 100 & $5.90 \mathrm{a}$ & 100 & $2.41 \mathrm{a}$ & 0 & \\
\hline 96 & $2.22 \mathrm{a}$ & 98 & $5.76 a$ & 86 & $2.08 \mathrm{a}$ & 2.5 & Thrice \\
\hline 98 & $2.27 \mathrm{~b}$ & 99 & $5.82 \mathrm{a}$ & 76 & $2.11 \mathrm{a}$ & 5 & \\
\hline
\end{tabular}

refined sugar yield, while applying humic acid increased refined sugar yield (Table 3 ). Accordingly, the maximum refined sugar yield $\left(6.35 \mathrm{t} \mathrm{ha}^{-1}\right)$ was achieved by 3 times application of $5 \mathrm{~L} \mathrm{ha}^{-1}$ humic acid. Similarly, Feckova $e t$ al. (2005) reported that the refined sugar yield was 25$36 \%$ higher than the control by applying humic acid, depending on the variety. Sadeghi-Shoae et al. (2013) also reported $27 \%$ increase of refined sugar yield in the plots containing humic acid.

The yield difference of refined sugar was not significant between the concentrations of 2.5 and $5 \mathrm{~L} \mathrm{ha}^{-1}$ of humic acid applied once or twice. The refined sugar yield is the result of root yield multiplied by the percentage of refined sugar and the increase of each content leads to the increased amount of white sugar. Accordingly, the yield decline of root in the treatment with $2.5 \mathrm{~L} \mathrm{ha}^{-1}$ concentration (39.45 and $40.1 \mathrm{t} \mathrm{ha}^{-1}$ in once and twice application(s)) compared to $5 \mathrm{~L} \mathrm{ha}^{-1}$ (41.45 and $43.84 \mathrm{t} \mathrm{ha}^{-1}$ in once and twice application(s)), with increased refined sugar percentage in $2.5 \mathrm{~L} \mathrm{ha}^{-1}$ concentration $(15.3 \%$ and $15.05 \%$ in once and twice application $(\mathrm{s})$ ) compared to $5 \mathrm{~L} \mathrm{ha}^{-1}$ concentration $(14.51 \%$ and $14.10 \%$ in once and twice application(s)) was compensated and the concentration differences were not significant in once and twice application(s). However, low increased of refined sugar percentage in three times application of $2.5 \mathrm{~L} \mathrm{ha}^{-1}(14.06 \%)$ compared to $5 \mathrm{~L} \mathrm{ha}^{-1}(14.02 \%)$ cannot compensate root yield decline. Thus, the sugar yield in three times application of $5 \mathrm{~L} \mathrm{ha}^{-1}$ humic acid had a significant difference compared with three times application of $2.5 \mathrm{~L} \mathrm{ha}^{-1}$ humic acid.

\section{Conclusions}

The experiment results showed that the use of humic acid can improve the quantity and quality of sugar beet yield, even grown on calcareous soils. The increased amount of sucrose and refined sugar content in all applications in concentration of $2.5 \mathrm{~L} \mathrm{ha}^{-1}$ humic acid was more than with $5 \mathrm{~L} \mathrm{ha}^{-1}$. Similarly, the content of molasses forming substances showed more reduction in 2.5 $\mathrm{L} \mathrm{ha}^{-1}$ than in $5 \mathrm{~L} \mathrm{ha}^{-1}$ treatment. Nevertheless, the trend of increasing content of sucrose and refined sugar was no associated with humic acid concentration. The maximum refined sugar yield $\left(6.35 \mathrm{t} \mathrm{ha}^{-1}\right)$, as the most important economic parameter of the yield, was achieved by 3 times application of $5 \mathrm{~L} \mathrm{ha}^{-1}$ humic acid.

\section{References}

Ayuso M, Hernandez T, Garcia C, Pascual JA (1996). Stimulation of barley growth and nutrient absorption by humic substances originating from various organic materials. Bioresource Technology 57(3):251-257.

Çelik H, Katkat AV, Aşık BB, Turan MA (2010). Effect of foliar-applied humic acid to dry weight and mineral nutrient uptake of maize under calcareous soil conditions. Communications in Soil Science and Plant Analysis 42(1):29-38.

Chen Y, Aviad T (1990). Effects of humic substances on plant growth. In: McCarthy P, Calpp CE, Malcolm RL, Bloom PR (Eds). Humic substances in soil and crop sciences: Selected readings. ASA and SSSA, Madison pp 161-186.

Chen Y, Schnitzer M (1978). Water surface tension of aqueous solutions of soil humic substances. Soil Science 125(1):7-15.

David PP, Nelson PV, Sanders DC (1994). A humic acid improves growth of tomato seedling in solution culture. Journal of Plant Nutrition 17(1):173-184.

Eyheraguibel B, Silvestre J, Morard P (2008). Effects of humic substances derived from organic waste enhancement on the growth and mineral nutrition of maize. Bioresource Technology 99(10):4206-4212.

Fagbenro JA, Agboda AA (1993). Effect of different levels of humic acid on the growth and nutrient uptake of teak seedings. Journal of Plant Nutrition 16(8):1465-1483.

Feckova J, Pacuta V, Cerny I (2005). Effect of foliar preparations and variety on sugar beet yield and quality. Journal of Central European Agriculture 6(3):295-308.

Food and Agriculture Organization of the United Nations (FAO) (1973). Soils Bulletin 21, Calcareous Soils.

Katkat AV, Çelik H, Turan MA, Asik BB (2009). Effects of soil and foliar applications of humic substances on dry weight and mineral nutrients uptake of wheat under calcareous soil conditions. Australian Journal of Basic and Applied Sciences 3(2):1266-1273.

Lee YS, Bartlett RJ (1976). Stimulation of plant growth by humic substances. Soil Science Society of America Journal 40(6):876-879. 
Leytem AB, Mikkelsen RL (2005). The nature of phosphorus in calcareous soils. Better Crops 89(2):11-13.

Lulakis MD, Petsas SI (1995). Effect of humic substances from vinecanes mature compost on tomato seedling growth. Bioresource Technology 54(2):179-182.

Muscolo A, Felicim M, Concheri G, Nardi S (1993). Effect of earthworm humic substances on esterase and peroxidase activity during growth of leaf explants of Nicotiana plumbaginifiolia. Biology and Fertility of Soils 15(2):127131.

Nardi S, Pizzeghello D, Muscolo A, Vianello A (2002). Physiological effects of humic substances on higher plants. Soil Biology and Biochemistry 34(11):1527-1536.

Russo RO, Berlyn GP (1990). The use of organic biostimulants to help low input sustainable agriculture. Journal of Sustainable Agriculture 1(2):19-42.

Rychcik B, Zawislak K (2002). Yields and root technological quality of sugar beet grown in crop rotation and long-term monoculture. Rostlinna Vyroba 48(10):458-462.

Sadeghi-Shoae M, Paknejad F, Hassanpour Darvishi H, Mozafari H, Moharramzadeh M, Tookalloo MR (2013). Effect of intermittent furrow irrigation, humic acid and deficit irrigation on water use efficiency of sugar beet. Annals of Biological Research 4(3):187-193.

SAS Institute (1988). SAS/STAT user's guide, release 6.03 . Cary, NC: SAS Institute.
Tahir MM, Khurshid M, Khan MZ, Abbasi MK, Kazmi MH (2011). Lignite-derived humic acid effect on growth of wheat plants in different soils. Pedosphere 24(1):124-131.

Tan KH (2003). Humic matter in soil and environment: Principles and controversies, $2^{\text {nd }}$ Ed CRC Press, New York.

Türkmen O, Dursun A, Turan M, Erdinç C (2004). Calcium and humic acid affect seed germination, growth, and nutrient content of tomato (Lycopersicon esculentum L.) seedlings under saline soil conditions. Acta Agriculturae Scandinavica Section B-Soil \& Plant Science 54(3):168174.

Vaughan D (1974). Possible mechanism for humic acid action on cell elongation in root segments of Pisum sativum under aseptic conditions. Soil Biology and Biochemistry 6:241247.

Vaughan D, MacDonald IR (1976). Some effects of humic acid on cation uptake by parenchyma tissue. Soil Biology and Biochemistry 8:421-425.

Visser SA (1985). Physiological action of humic substances on microbial cells. Soil Biology and Biochemistry 17:457-462.

Zhang X, Schmidt RE (1999). Antioxidant response to hormone-containing product in Kentucky bluegrass subjected to drought. Crop Science 39(2):545-551. 